\title{
ELECTROCHEMICAL CORROSION PERFORMANCE OF COMMERCIALLY USED ALUMINIUM ENGINE BLOCK AND PISTON IN 0.1M NaCl
}

\author{
M S Kaiser ${ }^{1 *}$, M R Qadir ${ }^{2}$ and Swagata Dutta ${ }^{3}$ \\ ${ }^{1}$ Directorate of Advisory, Extension and Research Services, Bangladesh University of Engineering and \\ Technology, Dhaka-1000, Bangladesh \\ ${ }^{2}$ Pilot Plant and Process Development Centre, Bangladesh Council of Scientific and Industrial Research, \\ Dhaka-1000, Bangladesh \\ ${ }^{3}$ Institute of Appropriate Technology, Bangladesh University of Engineering and Technology, Dhaka- 1000, \\ Bangladesh \\ "Corresponding e-mail: mskaiser@iat.buet.ac.bd
}

\begin{abstract}
The corrosion behaviour of commercially used aluminium engine block and piston were investigated in $0.1 \mathrm{M} \mathrm{NaCl}$ solution at room temperatures. The study was done by electrochemical method, using Tafel polarization and electrochemical impedance spectroscopy (EIS) techniques. The surface was characterized by optical microscope and scanning electron microscope (SEM). The results indicated differences in the charge transfer resistance of engine block and piston alloys. The current density $\left(I_{\text {corr }}\right)$ of engine block material showed higher value than that of piston material. The corrosion potential $\left(E_{\text {corr }}\right)$ and pitting corrosion potential $\left(E_{\text {pit }}\right)$ of piston material were shifted to the more noble direction. In aluminium piston alloy there seems to be uniform surface pits formations which are in fewer amounts as compared to those in engine block alloy. The corrosion performance of aluminium piston alloy was found to be higher than that of aluminium engine block due to the presence of $\mathrm{Ni}$ and lower percentage of $\mathrm{Fe}$ in aluminium piston alloy.
\end{abstract}

Keywords: Localized corrosion, aluminium-silicon alloys, SEM, corrosion potential, polarization resistance.

\section{INTRODUCTION}

Aluminum alloys with silicon as a major alloying element constitute a class of material, which provides the most significant part of all shaped castings manufactured, having a wide range of applications in the automotive and aerospace industries ${ }^{1,2}$. This is mainly due to the outstanding effect of silicon in the improvement of casting characteristics, combined with other physical properties such as mechanical properties and corrosion resistance. Recent articles on $\mathrm{Al}-\mathrm{Si}$ alloys have reported that coarser dendritic structures yield higher corrosion resistance than finer dendritic structures, and that this is associated with the morphology of the interdendritic eutectic mixture. It was also reported that the silicon content is another important parameter affecting mechanical and corrosion resistances ${ }^{3,4}$. Corrosion is the gradual chemical or electrochemical attack on a metal by its surroundings such that the metal is converted into an oxide, salt or some other compound which results in loss of strength, hardness, toughness and other desirable mechanical properties. All corrosion reactions are electrochemical in nature and depend on the operation of electrochemical cells at the metal surface $^{5-7}$. The corrosion resistance of aluminum is attributed to an exceptionally stable oxide film that forms on its surface. This film is resistant to attack from water and oxygen in a wide range of temperatures and $\mathrm{pH}$ levels, making aluminum alloys useful in a variety of environments. The adsorption of aggressive ions such as $\mathrm{Cl}^{-}$into the faults in the protective film, and their penetration and accumulation in these imperfections is considered one of the triggering factors of the process of nucleation of pitting ${ }^{8,9}$. In addition, another factor which is associated with the susceptibility of aluminium to pitting corrosion and other forms of localized corrosion is the electrochemical nature of the intermetallic phases ${ }^{10}$. As a result, often the corrosion behavior can be correlated with the difference in potential between the matrix and the intermetallic compounds present in the alloy ${ }^{11}$.

Corrosion studies of aluminium and aluminium alloys have received considerable attention by researchers because of their technological importance and industrial applications. Aluminium is second to iron in terms of production and consumption. Aluminium and aluminium alloys find applications, mainly in automobiles, aviation, household appliances; containers and electronic devices ${ }^{12}$. In the present paper, the processes of corrosion of a commercially available aluminium alloy engine block and piston in $0.1 \mathrm{MNaCl}$ solution were studied via electrochemical methods. The research has been directed towards studying the characteristics, condition of formation and morphology of attack. 


\section{EXPERIMENTAL}

The material used in the current study is a commercially used aluminium alloy engine block and piston. The alloys were analyzed both by wet chemical and spectrochemical methods. The chemical compositions of the alloys are given in Table 1 . The samples of $25 \times 10 \times 3 \mathrm{~mm}^{3}$ size obtained from the aluminium alloy engine block and piston were used to conduct the tests for studying the corrosion behaviour. The samples were wet-sanded mechanically with $\mathrm{SiC}$ papers of 220 and 1200 grit. Before use, the samples were degreased with ethanol of $99 \%$ purity and then rinsed with plenty of water. A computer-controlled Gamry Framework TM Series G 300'TM and Series G $750^{\text {TM }}$ Potentiostat/ Galvanostat/ZRA were used for the electrochemical measurements. The Potentiodynamic polarization studies were configured in cells, using three-electrode assembly with a saturated calomel reference electrode, a platinum counter electrode and the sample as working electrode in the form of coupons with exposed area of $0.3 \mathrm{~cm}^{2}(10 \mathrm{~mm} \times 3 \mathrm{~mm})$. The other surfaces were covered with Teflon tape and allowed to establish a steady-state open circuit potential (OCP). The potential range selected was -1 to $+1 \mathrm{~V}$ and measurements were made at a scan rate of $0.50 \mathrm{mV} / \mathrm{s}$. First 100s applied for achieving steady state OCP and for potential $-1 \mathrm{~V}$ to $+1 \mathrm{~V}$ immersion time was about 60 minutes. The corrosion current $\left(\mathrm{I}_{\text {corr }}\right)$, corrosion potential $\left(\mathrm{E}_{\text {corr }}\right)$ and pitting corrosion potential $\left(\mathrm{E}_{\mathrm{pit}}\right)$ were calculated from Tafel curve ${ }^{13}$. The tests were carried out at room temperature in solutions containing $0.1 \mathrm{M} \mathrm{NaCl}$ at a fixed and neutral $\mathrm{pH}$ value. The corroded samples were cleaned in distilled water and examined by Optical Microscope.

The corrosion rate was calculated following ASTM Standard G 102. The following equation was used to calculate the corrosion rate

$$
\mathrm{CR}=\frac{\mathrm{I}_{\text {corr }} \cdot \mathrm{K} \cdot \mathrm{EW}}{\mathrm{d} \cdot \mathrm{A}}
$$

where,

$\mathrm{CR}=$ corrosion rate

$\mathrm{I}_{\text {corr }}=$ corrosion current in amps

$\mathrm{K}=$ constant that defines the units for the corrosion rate (Here, $\mathrm{K}=3272$ mmpy)

$\mathrm{EW}=$ equivalent weight in grams/equivalent

$\mathrm{d}=$ density in grams $/ \mathrm{cm}^{3}$

$\mathrm{A}=$ sample area in $\mathrm{cm}^{2}$

\section{RESULTS AND DISCUSSIONS}

\section{Electrochemical measurements}

The data obtained were modeled and the equivalent circuit that best fitted to the experimental data is shown in Fig. 1. $R_{s}$ represent the ohmic solution resistance of the electrolyte. $R_{c t}$ and $C_{p}$ are the charge transfer resistance and electrical double layer capacitance respectively, which correspond to the Faradaic process at the alloy/media interface.

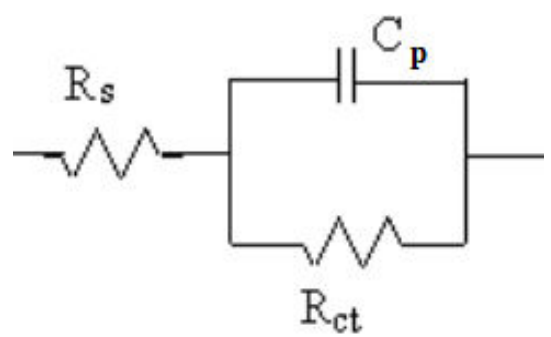

Figure 1. Electrical equivalent circuit used for fitting of the impedance data of aluminium engine block and piston in $0.1 \mathrm{M} \mathrm{NaCl}$ solution.

Figure 2 shows the Nyquist diagrams of the aluminium engine block and piston in $0.1 \mathrm{M} \mathrm{NaCl}$ in demineralized (DM) water. In Nyquist diagrams, the imaginary component of the impedance ( $\left.Z^{\prime \prime}\right)$ against real part ( $\left.Z^{\prime}\right)$ is obtained in the form of capacitive-resistive semicircle for each sample. The solution resistance of the alloys varies from $41-51 \Omega$ and the $R_{S}$ values of the alloys are very similar to each other. So there are insignificant changes of $\mathrm{R}_{\mathrm{s}}$ values for the alloys during EIS testing. The solution resistance is negligible with respect to $R_{c t}$ and the electrolyte behaves as a good ionic conductor. Impedance measurements showed that in $0.1 \mathrm{M} \mathrm{NaCl}$ solution, the charge transfer resistance $\left(\mathrm{R}_{\mathrm{ct}}\right)$ is higher for the piston alloy. For the engine block alloy, the charge transfer resistance $\left(\mathrm{R}_{\mathrm{ct}}\right)$ value in $0.1 \mathrm{M}$ $\mathrm{NaCl}$ solution is $5.51 \mathrm{k} \Omega$, and this is increased to $8.33 \mathrm{k} \Omega$ to the piston alloy. The increase in the charge transfer resistance indicates an increase in the corrosion resistance of the alloys ${ }^{14}$. Engine block and piston contain the different amount of alloying elements as shown in Table 1. The charge transfer resistance depends upon the intermetallics present in the alloys formed by the alloying elements ${ }^{15}$.

Potentiodynamic polarization curves of aluminium engine block and piston in $0.1 \mathrm{M} \mathrm{NaCl}$ solution are shown in Fig. 3. Table 2 shows the value of electrochemical parameters $\left(\mathrm{I}_{\text {corr }}, \mathrm{E}_{\text {corr }}, \mathrm{E}_{\text {pit }}\right.$ and corrosion rate) obtained from potentiodynamic

Table 1. Chemical composition for engine block and piston (wt \%)

\begin{tabular}{|c|c|c|c|c|c|c|c|l|}
\hline Alloy & $\mathrm{Si}$ & $\mathrm{Mg}$ & $\mathrm{Cu}$ & $\mathrm{Ni}$ & $\mathrm{Fe}$ & $\mathrm{Zn}$ & $\mathrm{Mn}$ & $\mathrm{Al}$ \\
\hline Block & 10.783 & 0.238 & 2.281 & 0.083 & 0.795 & 0.760 & 0.256 & $\mathrm{Bal}$ \\
\hline Piston & 9.764 & 0.492 & 2.446 & 0.278 & 0.400 & 0.104 & 0.495 & Bal \\
\hline
\end{tabular}




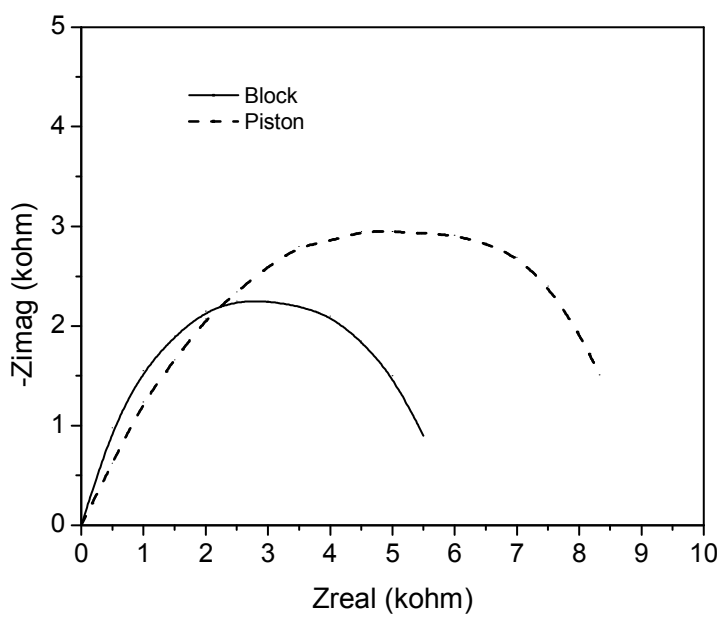

Figure 2. Nyquist plot for the aluminium engine block and piston in $0.1 \mathrm{M} \mathrm{NaCl}$ solution.

polarization curves. In the engine block alloy, the corrosion potential $\left(\mathrm{E}_{\text {corr }}\right)$ is $-764 \mathrm{mV}$, which is higher negative in value than that of piston alloy $(-622 \mathrm{mV})$. Pitting potential of the piston alloy also shifted to more positive values similar to corrosion potential. The pitting potential was $-489 \mathrm{mV}$ for block and $-345 \mathrm{mV}$ for piston. Anodic current density $\left(\mathrm{I}_{\text {corr }}\right)$ of engine block showed higher value than that of piston material. $\mathrm{I}_{\text {corr }}$ of engine block was $57.5 \mu \mathrm{A} / \mathrm{cm}^{2}$ and corrosion rate was 2.083 mmpy, whereas the $\mathrm{I}_{\text {corr }}$ value decreased for piston alloy to $50.9 \mu \mathrm{A} / \mathrm{cm}^{2}$ with corrosion rate of 1.848 mmpy.

The result was due to the presence of $\mathrm{Ni}$ and lower percentage of $\mathrm{Fe}$ in piston alloy as seen from Table 1. The elements present in the alloys caused the formation of micro-galvanic cells in $\alpha$-aluminium matrix. The different intermetallic compounds (like $\mathrm{Mg}_{2} \mathrm{Si}, \mathrm{Al}_{2} \mathrm{Cu}$, $\mathrm{Al}_{3} \mathrm{Ni}$ etc.) can lead to the formation of micro- galvanic cells because of the difference of corrosion potential between intermetallics and $\alpha$-aluminium matrix ${ }^{16}$. Ni forms $\mathrm{Al}_{3} \mathrm{Ni}$ and presents a thin and homogeneous distribution of this intermetallic compound in the aluminium matrix. The Ni-containing amorphous alloy showed a pitting potential greater than the Ni-free amorphous alloy. Comparing the amorphous alloys, the addition of $\mathrm{Ni}$ enhances the pitting potential to a greater extent even though both alloys are amorphous. The effect is pronounced even following devitrification. Although a significant decreases in pitting potential was observed by devitrification of both alloys. The aluminium piston alloy showed a mean pitting potential greater than aluminium engine block.

The cathode reaction of dissolved oxygen and formation of $\mathrm{OH}^{-}$ions occurs on $\mathrm{Al}_{3} \mathrm{Fe}$ particles. These ions react chemically with a protective $\mathrm{Al}_{2} \mathrm{O}_{3}$ film. Iron remains in the $\mathrm{Al}_{3} \mathrm{Fe}$ phase and the cathodic reaction is the reduction of oxygen on $\mathrm{Al}_{3} \mathrm{Fe}$ particles. When $\mathrm{Al}_{3} \mathrm{Fe}$ crystal appear in the structure the corrosion rate increases. This effect was pronounced in the engine block alloy due to the presence of higher percentage of $\mathrm{Fe}$ than that of piston alloy ${ }^{17}$.

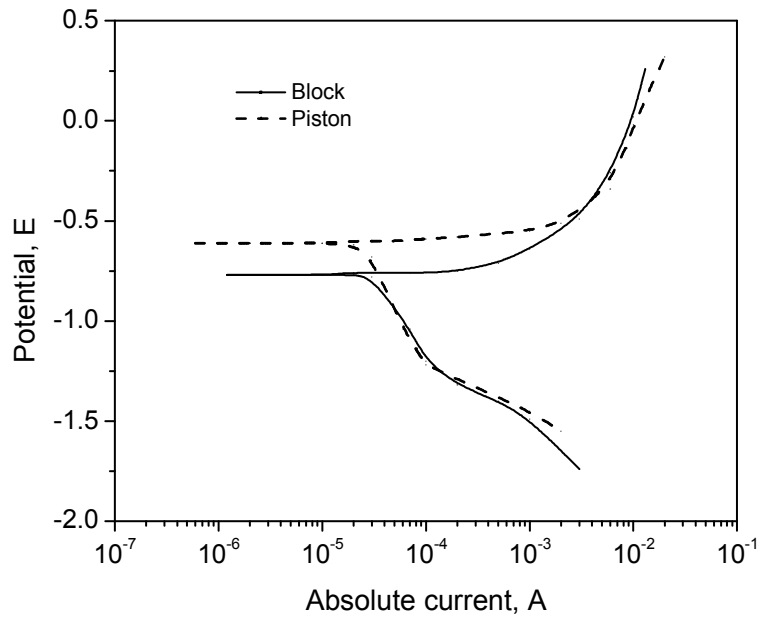

Figure 3. Tafel polarization curves for aluminium engine block and piston exposed to $0.1 \mathrm{M} \mathrm{NaCl}$ solutions at $25^{\circ} \mathrm{C}$.

Table 2. Electrochemical Test Result

\begin{tabular}{|c|c|c|c|c|}
\hline Alloy & $\mathrm{I}_{\text {corr }}(\mathrm{amp})$ & $\mathrm{E}_{\text {corr }}$ (volt) & $\begin{array}{c}\mathrm{E}_{\text {pit }} \\
\text { (volt) }\end{array}$ & CR (mmpy) \\
\hline Block & 0.0000575 & -0.764 & -0.489 & 2.083 \\
\hline Piston & 0.0000509 & -0.622 & -0.345 & 1.848 \\
\hline
\end{tabular}

\section{Optical micrographic observation}

Fig. $4 \mathrm{a}$ and $4 \mathrm{~b}$ show the optical micrograph of polished aluminium engine block and piston respectively before immersion into the corrosion medium. The samples has a microstructure characterized by an Al-rich dendritic matrix, $\alpha-\mathrm{Al}$ phase and a eutectic mixture in the interdendritic region formed by silicon particles, which are coarse and distributed in plate-like morphology, set in an Al-rich phase $^{18}$. In this type of image the precipitates of $\mathrm{Al}(\mathrm{Mn}$, $\mathrm{Fe}, \mathrm{Cu})$ are those that appear in the dark tone while those of $\mathrm{Al}(\mathrm{Si}, \mathrm{Mg})$ appear in a lighter tone.

In Fig. 5a and $5 \mathrm{~b}$ is seen that after electrochemical corrosion study, severe corrosion was observed. These findings primarily suggested that some traces of cracks and pronounced pits; indicative of pitting corrosion. The exposure surface shows evidence of localized attack at the location of the intermetallic caused by the dissolution of the matrix. In aluminium piston alloy there seems to be uniform surface pits formations which are in fewer amounts as compared to those in engine block alloy. Pits may be formed by intermetallic dropping out from the surface due to the dissolution of 
the surrounding matrix. Pitting develops as a two stage process with an initiation stage and a propagation stage. During the initiation stage the passive film is penetrated by aggressive ions such as chlorides. These pits compete amongst themselves and only a very small number eventually propagating. There was evidence of corrosion products in all the samples examined. The piston alloy showed better resistance to corrosion due to the presence of $\mathrm{Al}_{3} \mathrm{Ni}$. The $\mathrm{Ni}$ particles are distributed homogeneously in acicular forms inside the Al-Si matrix. The block alloy contained significant amount of $\mathrm{Fe}$ which made it prone to pitting corrosion $^{19}$.
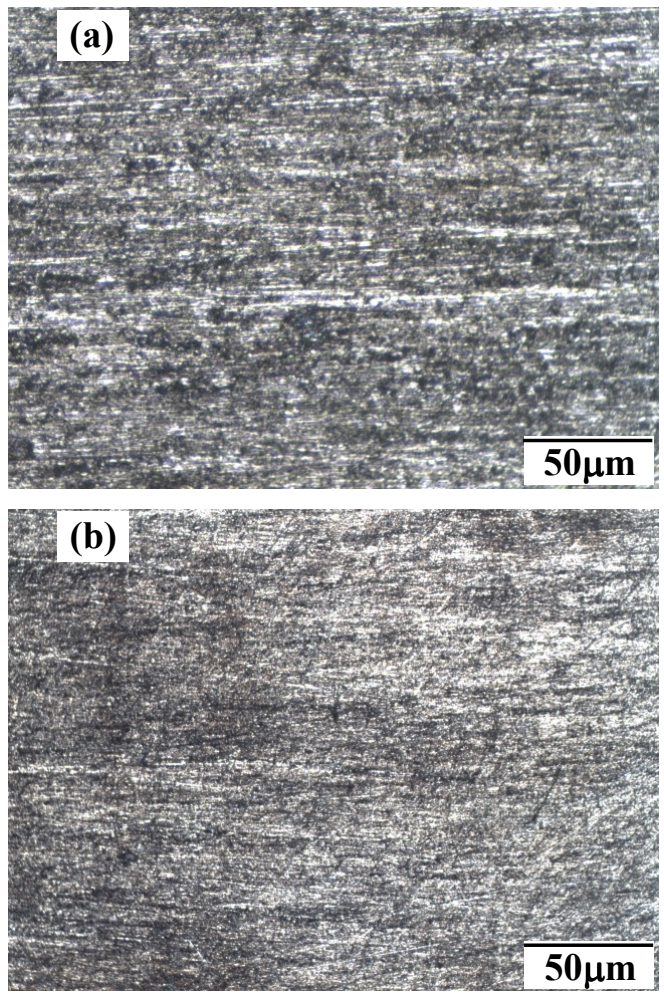

Figure 4. Microstructure of polished aluminium alloy a) engine block and b) piston before corrosion.

\section{SEM observation}

Fig. 6a and $6 \mathrm{~b}$ exhibits the SEM micrographs of as-received aluminium alloy engine block and piston respectively.

The microstructure is comprised of significant amount of primary $\mathrm{Al}$ dendrite, eutectic $\mathrm{Si}, \mathrm{Al}_{15}(\mathrm{Fe}$, $\mathrm{Mn})_{3} \mathrm{Si}_{2}, \mathrm{Mg}_{2} \mathrm{Si}$ and a few number of $\mathrm{Fe}$ - rich intermetallic phases on $\alpha$-Al matrix in the inter-dendritic region. The eutectic Si phase present in the alloy is flake-like with acicular morphologies. Piston alloy primarily contains two type of $\mathrm{Al}_{3} \mathrm{Ni}$ phase are the plate-like and needle-like morphologies [19, 20]. The Ni particles are distributed homogenously in acicular forms inside the Al-Si matrix without any cracks or voids between them. The Ni particles reacted with $\mathrm{Al}$ matrix forming $\mathrm{Al}_{3} \mathrm{Ni}$ intermetalics.
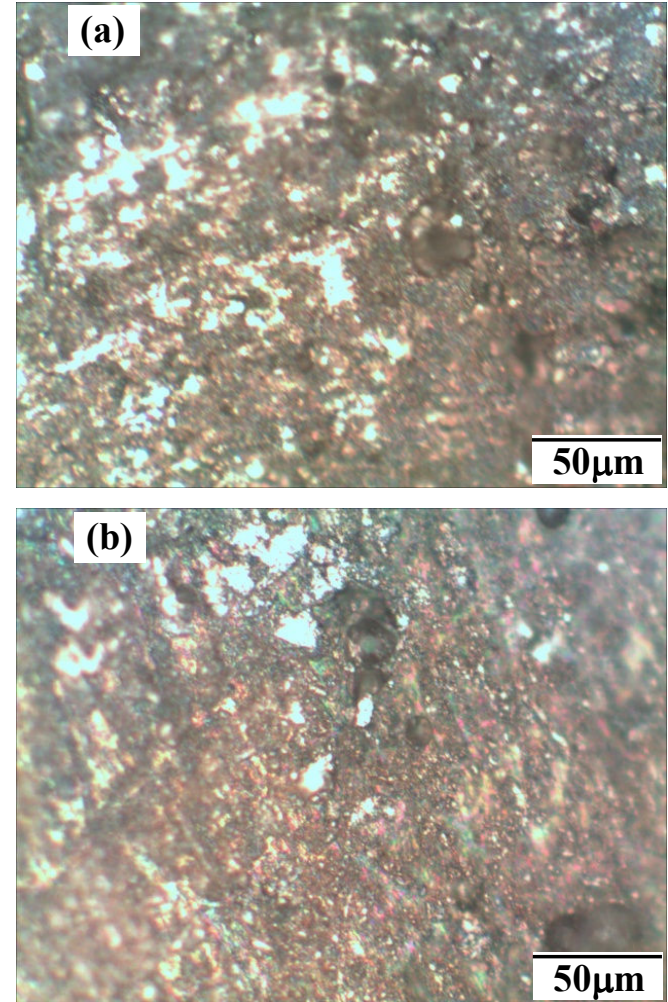

Figure 5. Microstructure of corroded aluminium alloy a) engine block and b) piston in $0.1 \mathrm{M} \mathrm{NaCl}$ solution.
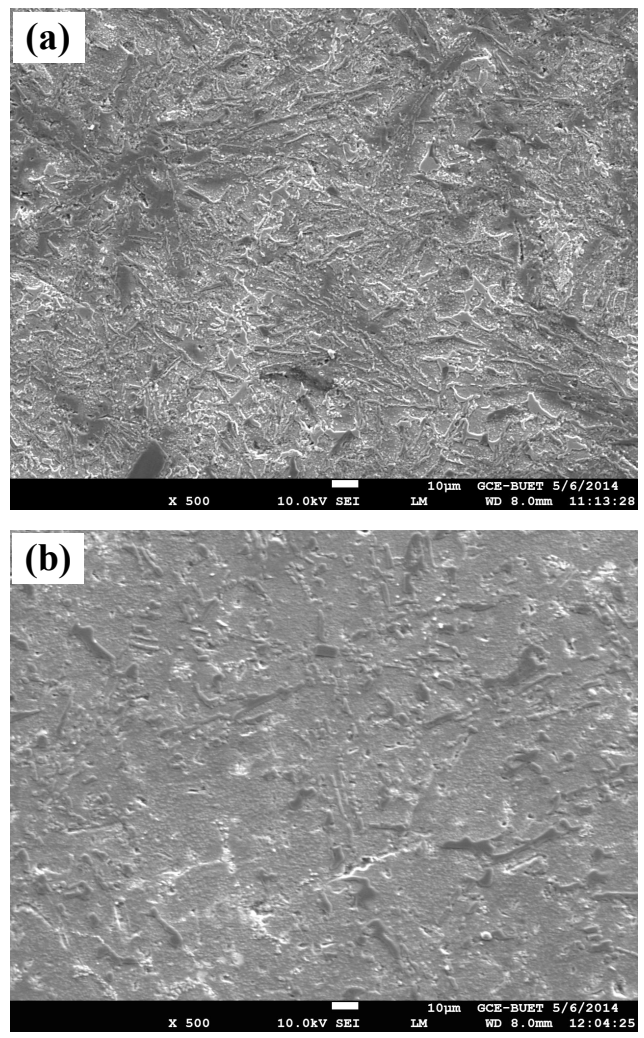

Figure 6. SEM images of as recived aluminium a) engine block and $b$ ) piston. 


\section{CONCLUSIONS}

The charge transfer resistance of the piston alloy showed the higher value due to present of intermettalics of different percentage than that of engine block. The current density $\left(\mathrm{I}_{\text {corr }}\right)$ of engine block material showed higher value than that of piston material. The corrosion potential $\left(\mathrm{E}_{\mathrm{corr}}\right)$ and pitting corrosion potential $\left(\mathrm{E}_{\mathrm{pit}}\right)$ of piston material were shifted to the more noble direction. In aluminium piston alloy there seems to be uniform surface pit formations which are in fewer amounts as compared to those in engine block alloy. The corrosion performance of aluminium piston alloy was found to be higher than that of aluminium engine block due to the presence of $\mathrm{Ni}$ and lower percentage of $\mathrm{Fe}$ in aluminium piston alloy.

\section{ACKNOWLEDGEMENTS}

This work is supported by CASR of Bangladesh University of Engineering and technology and is part of project "Studies of recrystallization, wear and corrosion behavior of aluminium piston and piston block". Thanks to Department of Glass and Ceramics Engineering, BUET and Bangladesh Council of Scientific and Industrial Research for providing the laboratory facilities.

\section{REFERENCES}

1. Dave M. M. and Kothari K. D., "Composite Material-Aluminium Silicon Alloy: A Review”, Indian Journal of Research, Vol. 2, No. 3, 2013, pp. 148-150. 2. Deuis R. L., Subramonian C. and Yellup J. M., "Reviews on the Influences of Alloying elements on the Microstructure and Mechanical Properties of Aluminum Alloys and Aluminum Alloy Composites", International Journal of Scientific and Research Publications, Vol. 2, No. 6, 2012 pp. 1-7.

3. Osorio W. R., Cheung N., Peixoto 1. C. and and Garcia A., "Corrosion Resistance and Mechanical Properties of an $\mathrm{Al} 9 \mathrm{wt} \% \mathrm{Si}$ Alloy Treated by Laser Surface Remelting", International Journal of Electrochemical Science, Vol. 4, 2009, pp. 820-831.

4. Goulart P. R., Spinelli J. E, Osorio W. R. and Garcia A., "Mechanical properties as a function of microstructure and solidification thermal variables of Al-Si castings", Materials Science and Engineering A, Vol. 421, No. 1, 2006, pp. 245-253.

5. Evans R. U., "An introduction to metallic corrosion", published by Edward Arnold publishers, 1963, London.

6. Abdulmaruf S. and Dajab D. D., "Corrosion behavior of Copper immersed in different environment", Materials Society of Nigeria (MSN) Zaria chapter book of proceedings, 3rd Edition, 2007, pp. 67-70.

7. Fontana M. G., "Corrosion Engineering", 2nd Edition, Mc-Graw-Hill Books, 1967, New York

8. Strehblow H. H., "Corrosion Mechanism in theory and practice”, Marcel Dekker, 1995, New York.
9. Sherif E. M., "Corrosion Behavior of Magnesium in Naturally Aerated Stagnant Seawater and 3.5\% Sodium Chloride Solutions", Int. J. Electrochem. Sci., Vol. 7, 2012, pp. 4235- 4249.

10. Sherif E. M. and Almajid A. A., "Corrosion of Magnesium/Manganese Alloy in Chloride Solutions and its Inhibition by 5-(3-Aminophenyl)-tetrazoleInt", International Journal of Electrochem. Science, Vol. 6, 2011, pp. 2131-2148.

11. Chaudhury S. K., Warke V., Shankar S and Apelian D., "Localized Recrystallization in Cast Al-Si-Mg Alloy during Solution Heat Treatment: Dilatometric and Calorimetric Studies. Metallurgical and materials Transactions A, Vol. 42A, 2011, pp. 3160-3169.

12. Prabhu D and Padmalatha R., "Studies of corosion of aluminium and 6063 aluminium alloy in phosphoric acid medium", International Journal of Chem. Tech Research, Vol.5, No.6, 2013, pp 2690-2705.

13. Thomson N. G. and Payer J. H., "DC Electrochemical Test Methods", National Association of Corrosion Engineers, 1998, Houston, Texas.

14. Hossain A., Gulshan F. and Kurny A. S. W., "Electrochemical investigation of corrosion behavior heat treated Al-6Si-0.5Mg-xCu $(\mathrm{x}=0,0.5,1,2$, and $4 \mathrm{wt} \%$ alloys", International Journal of Corrosion, Vol. 2014, 2014, pp. 1-6.

15. Zin I. M., Lyon S. B., Bilyi L. M. and Tymus M. B., "Specific features of the corrosion inhibition of an aluminum alloy by a nonchromate pigment mixture", Journal of Material Science, Vol. 44, No. 5, 2008, pp. 638-645.

16. Hossain A., Gafur M. A., Gulshan F. and Kurny A. S. W., "The effects of $2 \mathrm{wt} \% \mathrm{Cu}$ addition on the corrosion behavior of heat treated Al- $6 \mathrm{Si}-0.5 \mathrm{Mg}-2 \mathrm{Ni}$ Alloy", International Journal of Chemical, Nuclear, Materials and Metallurgical Engineering Vol. 8, No:7, 2014, pp. 685-689.

17. Seri O. "The effect of $\mathrm{NaCl}$ concentration on the corrosion behavior of aluminum containing iron" Corrosion Science, Vol. 36, No. 10, 1994, pp.1789-1803.

18. Osorio W. R., Cheung N., Peixoto L. C and Garcia A., "Corrosion resistance and mechanical properties of an $\mathrm{Al} 9 \mathrm{wt} \% \mathrm{Si}$ alloy treated by laser surface remelting", International Journal of Electrochemical Science, Vol. 4, 2009, pp-820-831.

19. Rana R. S., Purohit R. and Das S., "Reviews on the influences of alloying elements on the microstructure and mechanical properties of aluminium alloys and aluminium alloys composites", International Journal of Scientific and Research Publications, Vol. 2, No. 6, 2012, pp. 1-7.

20. Stadler F., Antrekowitsch H., Fragner W., Kaufmann H. and Uggowitzer P. J., "The effect of Ni on the high-temperature strength of Al-Si cast alloys", Materials Science Forum, Vol. 690, 2011, pp. 274-277. 